\title{
GAMBARAN TINGKAT PENGETAHUAN MAHASISWA TENTANG PENCEGAHAN PENULARAN COVID-19 DI AKADEMI KEPERAWATAN BAITUL HIKMAH BANDAR LAMPUNG
}

\author{
*Marliyana, Dimas Ning Pangesti, Ria Septiana \\ Akademi Keperawatan Baitul Hikmah Bandar Lampung, Indonesia \\ *Email : marliyanadifa@gmail.com
}

\begin{abstract}
Abstrak
Prevalensi Covid-19 di Indonesia 488.000 kasus, Pengetahuan mahasiswa tentang pencegahan penularan Covid-19 berkontribusi untuk memutus mata rantai Covid-19. Tujuan penelitian dilakukan untuk mengetahui karakteristik tingkat pengetahuan mahasiswa tentang pencegahan penularan covid-19 di akademi keperawatan baitul hikmah bandar lampung tahun 2021. Metode penelitian ini merupakan penelitian yang bersifat deskriptif menggunakan teknik non random sampling dengan jumlah responden 30 mahasiswa. Data dikumpulkan menggunakan kuesioner yang diisi melalui google form yang terdiri dari 30 item pernyataan. Data dianalisis menggunakan rumus distribusi frekuensi. Hasil terdapat kriteria tingkat pengetahuan mahasiswa tentang pencegahan penularan Covid-19 di akademi keperawatan baitul hikmah, baik 19 (63\%), cukup 9 (30\%), kurang 2 (7\%). Kesimpulan dari Gambaran tingkat pengetahuan mahasiswa tentang pencegahan penularan Covid-19 di akademi keperawatan baitul hikmah bandar lampung tahun 2021 dalam kategorik baik. Saran bagi penelitian selanjutnya diharapkan dapat melakukan penelitian lebih dalam lagi dengan tema melihat sikap atau prilaku mahasiswa tentang pencegahan penularan Covid-19
\end{abstract}

Kata kunci : Covid-19, pencegahan penularan, pengetahuan mahasiswa

\begin{abstract}
The prevalence of Covid-19 in Indonesia is 488,000 cases. Student knowledge about preventing the transmission of Covid-19 contributes to breaking the Covid-19 chain. The purpose of the study was to determine the characteristics of the level of student knowledge about preventing the transmission of Covid-19 at the Baitul Wisdom Nursing Academy in Bandar Lampung in 2021. This research method is a descriptive study using a non-random sampling technique with a total of 30 students as respondents. Data was collected using a questionnaire filled out via a google form consisting of 30 statement items. The data were analyzed using the frequency distribution formula. The results showed that there were criteria for the level of student knowledge about preventing transmission of Covid-19 at the Baitul Wisdom Nursing Academy, either 19 (63\%), enough 9 (30\%), less than 2 (7\%). The conclusion of the description of the level of student knowledge about the prevention of Covid-19 transmission at the Baitul Wisdom Nursing Academy in Bandar Lampung in 2021 is in the good category. Suggestions for further research are expected to be able to conduct more indepth research with the theme of seeing student attitudes or behavior about preventing the transmission of Covid-19
\end{abstract}

Keywords : Covid-19, prevention of transmission, student knowledge 


\section{PENDAHULUAN}

Covid-19 merupakan penyakit menular yang saat ini sedang dihadapi dunia. Penyakit Covid-19 saat ini sudah menjadi permasalahan global karena selain menyebabkan kematian juga penyebarannya yang sangat cepat. Penyakit Covid-19 disebut Emerging Infectious Disease (EIDs) yang menjadi kekhawatiran khusus dalam kesehatan masyarakat, karena penyakit ini selain menyebabkan kematian penyakit ini juga membawa dampak sosial dan ekonomi yang besar dalam dunia yang telah saling berhubungan saat ini (Kemenkes RI, 2020 dikutip dalam Winarti. dkk, 2020).

Pandemik Covid-19 saat ini telah menyerang 216 negara dengan jumlah kasus 7.805.148 orang terinfeksi dan 431.192 orang meninggal dunia. Sedangkan di Indonesia angka kejadian mencapai 488.000 kasus dengan tingkat kematian 0,03\% (Kemenkes RI, 2020 dikutip dalam Alfikrie. dkk, 2020). Penyebaran Covid-19 di Indonesia telah mencapai 34 provinsi, termasuk provinsi Lampung Dinas Kesehatan Lampung mencatat hingga kini kasus konfirmasi positif Covid-19 di provinsi ini mencapai 9.084 usai terdapat 165 penambahan pasien yang terinfeksi virus corona. (Dinkes Lampung, 2021). Penambahan 165 pasien ini tersebar di 12 kabupaten/kota di mana kasus Covid-19 dari Kota Bandar lampung berjumlah 43 orang (Dinkes Lampung, 2021). Studi pendahuluan lebih lanjut pada mahasiswa Akper Baitul Hikmah pada 23 orang mahasiswa menunjukan mahasiswa sudah pernah mendapatkan informasi tentang Covid-19.

Covid-19 dapat menular dari manusia ke manusia melalui kontak erat dan droplet, tidak melalui udara. Orang yang paling berisiko tertular penyakit ini adalah orang yang kontak erat dengan pasien covid-19 termasuk yang merawat pasien covid-19 (Kemenkes RI, 2020 dikutip dalam winarti dkk, 2020). Rekomendasi standar untuk mencegah penyebaran infeksi adalah melalui cuci tangan secara teratur, menerapkan etika batuk dan bersin, menghindari kontak secara langsung dengan ternak dan hewan liar serta menghindari kontak dekat dengan siapa pun yang menunjukkan gejala penyakit pernapasan seperti batuk dan bersin (Kemenkes RI, 2020 dikutip dalam winarti. dkk, 2020).

Penularan Covid-19 dapat dicegah dengan pengetahuan tentang pencegahan penularan yang baik dapat membuat seseorang memperoleh pengetahuan baru dan membuka wawasan berfikirnya (Listiani, 2015 dikutip dalam Sukesih. et al, 2020). Dampaknya, bagi orang yang berwawasan yaitu, perubahan perilaku, hal ini berarti semakin baik pengetahuan seseorang maka prilakunya pun semakin baik (Listiani, 2015 dikutip dalam Sukesih. et al, 2020). 
Penelitian yang di lakukan oleh Hamzah B (2020), "Gambaran pengetahuan dan sikap mahasiswa kesehatan tentang upaya pencegahan penyebaran covid-19”. dari 107 mahasiswa yang menjadi responden terdapat $(91,6 \%)$ yang mempunyai pengetahuan baik dan terdapat $(8,4 \%)$ yang mempunyai pengetahuan kurang baik tentang upaya pencegahan penyebaran Covid-19, selanjutnya terdapat $(94,4 \%)$ mahasiswa yang mempunyai sikap positif dan (5,6\%) mahasiswa yang mempunyai sikap negatif tentang upaya pencegahan penyebaran Covid19. Simpulan: Sebagian besar mahasiswa STIKES Graha Medika mempunyai pengetahuan yang baik $(91,6 \%)$ dan sikap positif $(94,4 \%)$ tentang upaya pencegahan penyebaran Covid-19 di Kotamobagu.

Berdasarkan studi pendahuluan yang penulis lakukan pada tanggal 25 januari 2021 terhadap mahasiswa Akper Baitul Hikmah masih banyak yang belum menggunakan masker, tidak menjaga jarak, masih banyak yang tidak mencuci tangan, berbicara berdekatan dan membuka maskernya. Studi pendahuluan lebih lanjut pada mahasiswa Akper Baitul Hikmah pada 23 orang mahasiswa menunjukan mahasiswa sudah pernah mendapatkan informasi tentang Covid-19 melalui media online dan sosial media mahasiswa mengatakan kebingungan tentang pencegahan penularan Covid-19 karena informasi yang didapat simpang siur. Berdasarkan fenomena di atas penulis tertarik untuk melakukan penelitian tentang "Gambaran Tingkat Pegetahuan Mahasiswa Tentang Pencegahan Penularan Covid-19 Di Akademi Keperawatan Baitul Hikmah Bandar Lampung Tahun 2021"

\section{METODOLOGI}

Penelitian deskriptif merupakan penelitian yang bertujuan untuk mendeskripsikan atau memaparkan peristiwa-peristiwa penting yang terjadi pada masa kini. Deskripsi peristiwa dilakukan secara sistematis dan lebih menekankan pada data faktual dari pada penyimpulan (Nursalam, 2016 dikutip dalam Adnyani, 2019).

Sampel dalam karya tulis ilmiah ini 30 orang mahasiswa Akper Baitul Hikmah Bandar Lampung. Sampling adalah menyeleksi porsi dari populasi untuk dapat mewakili populasi. Teknik sampling yang digunakan dalam karya tulis ilmiah ini menggunakan non random sampling (Notoatmodjo, 2012 dikutip dalam Anggito \& Setiawan, 2018).

Instrumen dan alat ukur dalam karya tulis ilmiah ini berupa pertanyaan tentang mengukur tingkat pengetahuan mahasiswa tentang pencegahan penularan covid-19 menggunakan modifikasi kuesioner dari hasil penelitian (Darsini, et, al 2020), diberikan skor 1 jika jawaban benar dan diberikan skor 0 jika jawaban salah skor tertinggi 1 dan skor 
terendah 0 kuesioner penelitian tentang pencegahan penularan covid-19 terdiri dari 30 butir pertanyaan.

Prosedur pengumpulan data, Penulis akan membagikan kuesioner link google from kepada responden melalui grup whatsaap. Tahap pengumpulan data, mengurus perizinan dengan institusi Akademi Keperawatan Baitul Hikmah Bandar Lampung untuk melakukan karya tulis ilmiah, menjelaskan maksud, tujuan, dan waktu karya tulis ilmiah kepada Yayasan Baitul Hikmah Kalimosodo Akademi Keperawatan Baitul Hikmah Bandar Lampung, Persiapan responden sesuai kriteria inklusi. Pelaksanaan, membuat grup whatsapp untuk responden di karenakan sedang masa pandemic Corona Virus Disease 2019 (Covid19) dan untuk membagikan link google form, mengucap salam, menjelaskan kepada responden apa yang dilakukan, mengapa hal tersebut perlu dilakukan, dan bagaimana responden dapat bekerja sama, yang sudah tertera di google form, meminta untuk memilih setuju/tidak setuju pada link google form informed consent sebagai bukti persetujuan menjadi subyek karya tulis ilmiah, mengecek nama dan kelengkapan identitas responden untuk menghidari kesalahan atau kekurangan data dari responden, membagikan link google form untuk mengisi kuesioner kepada responden tentang pertanyaan tingkat pengetahuan mahasiswa pencegahan penularan covid-19 melalui grup whatsapp, Setelah membagikan link kuesioner responden mulai mengisidan jika ada yang belum jelas atau ada kendala koneksi boleh ditanyakan pada peneliti, hari kedua sampai hari ketujuh diingatkan kembali digrup untuk mengisi link kusioner, hari ketujuh 30 responden sudah mengisi semua kuesioner, menjaga privasi responden. Pelaporan, melakukan pengolahan data, menyajikan hasil pengolahan dan atau hasil karya tulis ilmiah dalam bentuk table atau narasi dan persentasi.

Analisis data karya tulis ilmiah menggunakan analisis deskriptif yaitu analisis data dilakukan dengan cara score. Dimana mahasiswa memilih setiap jawaban dari pernyataan yang menurutnya " BENAR dan SALAH". Hasil jawaban mahasiswa yang telah diberikan pembobotan di jumlahkan dan di bandingkan dengan jumlah score yang di harapkan lalu dikalikan 100\%. Langkahlangkah pengolahan data editing, coding, processing, cleaning, tabulating.

Penelitian ini menggunakan etik penelitian yaitu: informed consent (penjelasan dan persetujuan), anonimty (tanpa nama), confidentiality (kerahasiaan).

\section{HASIL}

\section{Karakteristik responden}

Diketahui bahwa mahasiswa akper baitul hikmah Bandar lampung mayoritas berjenis kelamin perempuan 18 (60\%), laki-laki 12 
(40\%), dan agama mahasiswa 100\% islam, pendidikan terakhir 100\% SMA, umur mahasiswa Akper Baitul Hikmah Bandar Lampung 19-22 tahun.

Karakteristik responden dapat dilihat pada tabel berikut :

Tabel 1. Jenis kelamin

\begin{tabular}{cccc}
\hline No. & Jenis kelamin & $\boldsymbol{F}$ & $\mathbf{\%}$ \\
\hline 1 & Laki-laki & 12 & $40 \%$ \\
2 & Perempuan & 18 & $60 \%$ \\
\hline & Jumlah & $\mathbf{3 0}$ & $\mathbf{1 0 0 \%}$ \\
\hline
\end{tabular}

Tabel 2. Agama

\begin{tabular}{cccc}
\hline No. & Agama & $\boldsymbol{F}$ & $\mathbf{\%}$ \\
\hline 1 & Islam & 30 & $100 \%$ \\
2 & Kristen protestan & 0 & 0 \\
3 & Kristen katolik & 0 & 0 \\
4 & Hindu & 0 & 0 \\
5 & Budha & 0 & 0 \\
6 & Konghucu & 0 & 0 \\
\hline & Jumlah & $\mathbf{3 0}$ & $\mathbf{1 0 0 \%}$ \\
\hline
\end{tabular}

Tabel 3. Pendidikan terakhir

\begin{tabular}{|c|c|c|c|}
\hline No. & $\begin{array}{c}\text { Pendidikan } \\
\text { terakhir }\end{array}$ & $F$ & $\%$ \\
\hline 1 & Tidak sekolah & 0 & $0 \%$ \\
\hline 2 & SD & 0 & $0 \%$ \\
\hline 3 & SMP & 0 & $0 \%$ \\
\hline 4 & SMA & 30 & $0 \%$ \\
\hline \multirow[t]{2}{*}{5} & Perguruan tinggi & 0 & $0 \%$ \\
\hline & Jumlah & 30 & $100 \%$ \\
\hline
\end{tabular}

Tabel 4. Umur

\begin{tabular}{cccc}
\hline No. & Umur & $\boldsymbol{F}$ & $\mathbf{\%}$ \\
\hline 1 & 19 thn & 9 & $30 \%$ \\
2 & 20 thn & 8 & $27 \%$ \\
3 & 21 thn & 7 & $23 \%$ \\
4 & 22 thn & 6 & $20 \%$ \\
\hline & Jumlah & $\mathbf{3 0}$ & $\mathbf{1 0 0 \%}$ \\
\hline
\end{tabular}

\section{Hasil kuesioner pencegahan penularan}

\section{Covid-19}

\section{Tabel 5}

Distribusi frekuensi berdasarkan kuesioner pencegahan penularan Covid-19 di Akper Baitul Hikmah Bandar Lampung

\begin{tabular}{|c|c|c|c|}
\hline No. & $\begin{array}{c}\text { Hasil kuesioner } \\
\text { pencegahan } \\
\text { penularan Covid- } \\
19\end{array}$ & $F$ & $\%$ \\
\hline 1 & Baik & 19 & $63 \%$ \\
\hline 2 & Cukup & 9 & $30 \%$ \\
\hline \multirow[t]{2}{*}{3} & Kurang & 2 & $7 \%$ \\
\hline & Jumlah & 30 & $100 \%$ \\
\hline
\end{tabular}

Berdasarkan tabel 5 diatas dapat dilihat bahwa dari 30 responden hasil kuesioner pencegahan penularan baik 19 (63\%), cukup 9 (30\%), dan kurang 2 (7\%).

\section{PEMBAHASAN}

Hasil kuesioner pencegahan penularan Covid19. Dari hasil penelitian yang dilakukan pada 30 responden menunjukkan tingkat pengetahuan mahasiswa tentang pencegahan penularan Covid-19 di Akademi Keperawatan Baitul Hikmah Bandar Lampung Tahun 2021. Responden yang menjawab baik sebanyak 19 orang (63\%) tingkat pengetahuan baik. Responden yang menjawab cukup sebanyak 9 orang (30\%) tingkat pengetahuan cukup, dan responden yang menjawab kurang sebanyak 2 orang $(7 \%)$ tingkat pengetahuan kurang.

Menurut analisa peneliti tingkat pengetahuan mahasiswa tentang pencegahan penularan Covid-19 di Akademi Keperawatan Baitul Hikmah Bandar Lampung sesuai data yang di dapatkan bahwa yang menjawab kuesioner baik sebanyak 19 orang (63\%) tingkat pengetahuan baik. Pengetahuan mahasiswa baik tentang pencegahan penularan Covid-19 di Akademi Keperawatan Baitul Hikmah 
Bandar lampung tahun 2021 akan tetapi masih banyak mahasiswa yang tidak melakukan pencegahan penularan di Akademi Keperawatan Baitul Hikmah mereka tidak mengaplikasikan pada kehidupan sehari-hari seperti di Akper Baitul Hikmah Bandar Lampung. Berdasarkan data yang didapatkan mahasiswa yang menjawab kuesioner cukup sebanyak 9 orang (30\%) tingkat pengetahuan cukup, dan responden yang menjawab kurang sebanyak 2 orang (7\%) tingkat pengetahuan kurang.

Hasil penelitian ini sesuai dengan penelitian yang di lakukan oleh Hamzah B (2020), "Gambaran pengetahuan dan sikap mahasiswa kesehatan tentang upaya pencegahan penyebaran covid-19”. dari 107 mahasiswa yang menjadi responden terdapat $(91,6 \%)$ yang mempunyai pengetahuan baik dan terdapat $(8,4 \%)$ yang mempunyai pengetahuan kurang baik tentang upaya pencegahan penyebaran Covid-19, selanjutnya terdapat $(94,4 \%)$ mahasiswa yang mempunyai sikap positif dan (5,6\%) mahasiswa yang mempunyai sikap negatif tentang upaya pencegahan penyebaran Covid19. Simpulan: Sebagian besar mahasiswa STIKES Graha Medika mempunyai pengetahuan yang baik $(91,6 \%)$ dan sikap positif $(94,4 \%)$ tentang upaya pencegahan penyebaran Covid-19 di Kotamobagu.

\section{KESIMPULAN}

Dari hasil penelitian mengenai gambaran tingkat pengetahuan mahasiswa tentang pencegahan penularan Covid-19 di Akademi Keperawatan Baitul Hikmah Bandar Lampung Tahun 2021.

Karakteristik responden berdasarkan jenis kelamin laki-laki dan perempuan, karakteristik agama responden 100\% islam, karakteristik pendidikan terakhir 100\% SMA, karakteristik berdasarkan umur responden 1922 tahun.

Sebagian besar tingkat pengetahuan mahasiswa tentang pencegahan penularan Covid-19 responden masuk dalam kategorik baik dengan jumlah 30 responden terdapat 19 (63\%) dengan tingkat pengetahuan mahasiswa tentang pencegahan penularan Covid-19 baik, 9 (30\%) dengan tingkat pengetahuan mahasiswa tentang pencegahan penularan Covid-19 cukup, 2 (7\%) dengan tingkat pengetahuan mahasiswa tentang pencegahan penularan Covid-19 kurang.

Saran bagi peneliti selanjutnya diharapkan dapat melakukan penelitian lebih dalam lagi dengan tema melihat sikap atau prilaku mahasiswa tentang pencegahan penularan Covid-19.

\section{KEPUSTAKAAN}

Alfikrie. F. dkk, (2021). Pengetahuan Dan Sikap Mahasiswa Dalam Pencegahan Covid-19. BORNEO NURSING JOURNAL (BNJ) Vol. 3 No. 1 Tahun 
2021. Di unduh pada tanggal 25

januari

2021

dari

https://akperyarsismd.e-

journal.id/BNJ/article/view/33

Anggito, A., \& Setiawan, J. (2018). Metodologi penelitian kualitatif. CV Jejak (Jejak Publisher). Di unduh pada tanggal 25 februari 2021 dari https://books.google.co.id/books/about Metodologi_penelitian_kualitatif.html ?id=59V8DwAAQBAJ\&redir_esc $=y$

B., H. (2020). Gambaran Pengetahuan dan Sikap Mahasiswa Kesehatan tentang Upaya Pencegahan Penyebaran COVID-19. Bali Health Published Journal, 2(1), 1-11. Retrieved from http://ejurnal.stikeskesdamudayana.ac. id/index.php/bhpj/article/view/199

Dinkes , (2021). Dinkes: Pasien Covid-19 di Lampung Bertambah 165 Orang. Di unduh pada tanggal 3 februari 2021 dari

https://www.republika.co.id/berita/qng 0ot349/dinkes-pasien-covid19-dilampung-bertambah-165-orang

Sukesih. S. et al, (2020). Pengetahuan Dan Sikap Mahasiswa Kesehatan Tentang Pencegahan Covid-19 Di Indonesia. Jurnal Ilmu Keperawatan dan Kebidanan Vol.11 No.2 (2020) 258264. Di unduh pada tanggal 8 februari 2021

dari http://dx.doi.org/10.26751/jikk.v11i2. 835

Tiarm adnyani. (2019). Metodelogi penelitian. Di unduh pada tanggal 2 maret 2021 dari http://repository.poltekkesdenpasar.ac.id/4944/5/BAB\%20IV\%2 0Metodelogi\%20Penelitian.pdf

Winarti. R. dkk, (2020). Kajian Pengetahuan Mahasiswa Akper Hermina Manggala Husada Tentang Covid 19 Dan Cara Pencegahannya. Jurnal Ilmiah Keperawatan Altruistik (JIKA) Vol.3 / No.2 / Oktober 2020 : 1 - 9. Di unduh pada tanggal 25 januari 2021 dari https://doi.org/10.48079/Vol3.Iss2.64 